\title{
Karayollart Motorlu Araçlar Zorunlu Mali Sorumluluk Sigortasında Fiyatlama Rejimi ve Riskli Sigortalılar Havuzuna Illişkin Değerlendirme
}

\author{
The Pricing Rejime Of Highways Motor Vehicles Compulsory Third Party Liability \\ Insurance And An Assessment On The Risky-Insureds Pool
}

Muharrem UMUT*

$\ddot{O} Z$

Türk sigortaclllk sektöründe sorumluluk sigortalarının payı ve önemi dünya uygulamalarına benzer şekilde gittikçe artmaktadır. Sorumluluk sigortalarındaki Karayolları Motorlu Araçlar Zorunlu Mali Sorumluluk Sigortasının (zorunlu trafik sigortasının) yeri ise hayati önemdedir. Sigortalılar için yaptırılması ve sigorta şirketleri için de sunulması zorunluluğu bulunan zorunlu trafik sigortasının, gerek sigorta şirketlerinin portföylerindeki ağırlı̆̆ gerekse ülkemizdeki yayginlı̆̆ına bağlı olarak bilinirliği en fazla olan sigorta türüdür. Bu nedenle, kamu otoritesince bu sigortaya yönelik yapılan herhangi bir müdahale sonucunda ilgili tüm taraflardan olumlu veya olumsuz tepkiler alınmakta ve uzun süre tartışılmaktadır. Söz konusu sigortada duyarlllı̆ı̆n en fazla oluştuğu, diğer ifadeyle en çok tepkilere neden olduğu konu ise şüphesiz fiyat seviyesidir. Fiyat seviyesine bağlı olarak zaman içinde kamu otoritesince çeşitli müdahale ve düzenlemeler yapılmış olup temel amacı, primlerin makul oranlara getirilmesi olmuştur. Nitekim 2015 yıl ve sonrasında fiyatlarda yaşanan yükselişler sonucu, önce 2017 yllinda zorunlu trafik sigortast primlerinde tavan fiyatlar belirlenmiş, sonrasında ise riskli sigortalılar için bir havuz oluşturulmuştur. Bu çallşmada, Türk Sigortacllı sektöründe önemli bir yere ve paya sahip olan ve sigorta türü bakımindan ülkemizde en fazla yayginlı̆ğ haiz zorunlu trafik sigortasinın mahiyetine, kapsamına ve sunduğu teminatlara yer verilmiş, serbest tarifeye geçişle birlikte zaman içinde sigorta fiyatlarında yaşanan dalgalanmalara bağlı olarak kamu otoritesince yapılan müdahalelere ve düzenlemelere nedenleriyle birlikte yer verilmiştir. Daha sonra, son zamanlarda yaşanan fiyat yükselişlerine yönelik olarak kamu otoritesince getirilen tavan fiyat ve riskli sigortalılar havuzu uygulamalarına ilişkin açıklamalarda bulunularak gelecek dönemlerdeki olası etkileri değerlendirilmiştir.

ANAHTAR KELIMELER

Türk Sigortacılık Sektörü, Zorunlu Trafik Sigortası, Kamu Otoritesi, Tavan Fiyat, Riskli Sigortalılar Havuzu

\begin{abstract}
The share and importance of liability insurances in the Turkish insurance sector is increasing in a manner similar to the world practices. The place of Motor Vehicles Compulsory Third Party Liability Insurance (compulsory traffic insurance) in the liability insurance is vital as well. Being mandatory for the insured and submitted by the insurers, it is the type of insurance that has the highest awareness depending upon both the weight of the insurance companies in their portfolios and the prevalence in our country. Therefore, as a result of any intervention by the public authority against this insurance, positive or negative responses are received from all parties related and discussed for a long time in public. The issue in which the sensitivity occurs the most in the mentioned insurance, in other words, causes the most reactions is undoubtedly the price level. Depending on the price level, various interventions and regulations were made by the public authority over time, which their purpose was to bring the premiums to reasonable rate. In fact, as a result of price increases in 2015 and after, ceiling prices were determined first in the insurance premiums in 2017 and then pool was established for risky-insured people. In this study, the nature, scope and provided coverages of the insurance, having a big share in Turkish Insurance sector and the most prevalence in terms of insurance type, has been included. Furthermore, the interventions and regulations due to the fluctuations in insurance prices in time with the transition to the free tariff are included with their reasons. Then, the possible effects in the future periods were evaluated by making explainations about iplementations of the ceiling price and the pool of risky insurers introduced by the public authority for the recent price increases.
\end{abstract}

\section{KEYWORDS}

Turkish insurance sector, Compulsory third party liability insurance, Public authority, Ceiling-price, Risky insureds pool.

\begin{tabular}{|c|c|c|}
\hline & $\begin{array}{c}\text { Makale Geliş Tarihi / Submission Date } \\
\text { 30.12.2019 }\end{array}$ & $\begin{array}{c}\text { Makale Kabul Tarihi / Date of Acceptance } \\
22.04 .2020\end{array}$ \\
\hline & \multicolumn{2}{|c|}{$\begin{array}{l}\text { Umut, M. (2020). Karayolları Motorlu Araçlar Zorunlu Mali Sorumluluk Sigortasında Fiyatlama Rejimi ve Riskli } \\
\text { Sigortalılar Havuzuna İlişkin Değerlendirme. Selçuk Üniversitesi Sosyal Bilimler Meslek Yüksekokulu Dergisi, } 23 \text { (1), } \\
\text { 358-371. }\end{array}$} \\
\hline
\end{tabular}

* Dr. Öğr. Üyesi, Ankara Hacı Bayram Veli Üniversitesi, Bankacılık ve Sigortacilık Yüksek Okulu, muharrem.umut@ gmail.com, ORCID: 00000002-9213-1440 


\section{GíRiş}

Türk Sigortacılık Sektöründe sigorta şirketleri tarafından can, finansal, kredi, tarım, hukuksal koruma, mal ve sorumluluk sigortaları alanlarında birçok sigorta ürünü sunulmaktadır. Bunlar arasında sigortacılık sektörü açısından sorumluluk sigortaları önemli bir yer tutmakta olup, sektör açısından ağırlığı her geçen gün artmaktadır. Sorumluluk sigortaları arasında ise Karayolları Motorlu Araçlar Zorunlu Mali Sorumluluk

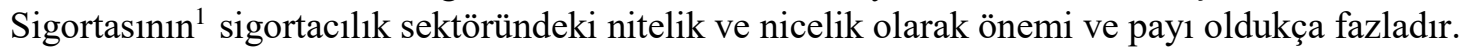

Bir üçüncü şahıs sorumluluk sigortası olan ve aynı zamanda yaptırılması mecburi olan Zorunlu trafik sigortası, ülkemizdeki en eski sigorta türlerinden biridir (Yalçınkaya, 2019; 404). Nitekim anılan sigorta "zorunlu mali sorumluluk sigortası" adıyla ilk defa 21.12.1959 tarih ve 7397 sayılı Sigorta Murakabe Kanununda yer almış, daha sonra 13.10.1983 tarih ve 2918 sayılı Karayolları Trafik Kanunu çerçevesinde araç işletenlerine tahmil edilen sorumluluğun yasal çerçevesi tanımlanmıştır (Ulaş, 1992; 128). Zorunlu trafik sigortası Türk sigortacılık sektöründe sorumluluk sigortaları içinde en yüksek paya sahiptir. ${ }^{2}$ Kamu otoritesi tarafından sigortalılar için yaptırılması ve sigorta şirketleri için de sunulma zorunluluğu bulunan zorunlu trafik sigortasının, gerek sigorta şirketlerinin portföylerindeki ağırlığı gerekse ülkemizdeki yaygınlığına bağlı olarak bilinirliği fazladır. Buna bağlı olarak, bu sigortaya yapılan düzenlemeler ile alınan tedbirlerin neticesinde kısa süre içerisinde olumlu veya olumsuz tepkiler alınmakta ve sektör katılımcıları tarafından tartışılmaktadır. Söz konusu sigortada duyarlılığın en fazla oluştuğu husus şüphesiz fiyat seviyesidir.

Türkiye İstatistik Kurumu'nun açıkladığı ulaştırma rakamları itibariyle, 2018 yılı sonu için Türkiye'de kayıtlı araç sayısı yaklaşık 22,8 milyondur (Türkiye İstatistik Kurumu, 2019). Söz konusu araçların tümü için Zorunlu trafik sigortası yaptırılmasına yönelik yasal zorunluluk bulunmaktadır. Bu itibarla, söz konusu sigorta toplumun çok büyük bir kesimini doğrudan veya dolaylı olarak etkilemekte ve bu sigortada yapılan fiyat ayarlamaları kişi ve kurumların bütçelerinde kendini hissettirmektedir. Dolayısıyla Zorunlu trafik sigortasındaki prim fiyatlarında yapılacak değişikliklerin, bu etkiler dikkate alınarak yapılması ve hakkaniyet ve adaleti sağlayacak şekilde makul bir fiyat politikasını öncelemesi hedeflenmelidir.

Zorunlu trafik sigortasında fiyatların belirlenmesine yönelik kamu politikası çeşitli nedenlerle zaman içinde değişime uğramıştır. Daha önce tarife fiyatlarının kamu otoritesi tarafindan belirlenmesi şeklindeki uygulama 2008 yılında terk edilerek prim fiyatlarının piyasada serbestçe oluşturulması benimsenmiştir. Akabinde ise önce Zorunlu trafik sigortası primlerinde tavan fiyatlar belirlenmiş ve riskli sigortalılar için havuz oluşturulmuştur.

$\mathrm{Bu}$ çalışmada, söz konusu fiyat politikalarının değişim sürecinin ele alınması ile birlikte en son kurulan riskli sigortalılar havuzunun işleyiş yapısı sunulmakta ve havuz uygulaması değerlendirilmektedir. Diğer taraftan, bu çalışmanın kuruluş tarihi itibariyle havuz uygulaması henüz çok yeni olduğundan, yıllar içinde havuz bünyesinde oluşacak istatistiki verilerle yapılacak çalışmalara temel oluşturacağı düşünülmektedir.

\section{ZORUNLU TRAFÍK SIGGORTASI VE KAPSAMINDAKİ TEMINATLAR}

Motorlu bir aracın karayollarında işletilmesi esnasında, herhangi bir kişinin zarara uğramasına sebep olunması durumunda, araç işleteninin zarara uğrayan kişilere karşı olan sorumluluğunu belirli limitler içerisinde karşılamayı hedefleyen ve 2918 sayılı Kanun ile yapılması zorunlu kılınan sorumluluk sigortası türü, zorunlu trafik sigortasıdır. Nitekim anılan Kanun karayollarında, can ve mal güvenliği bakımından trafik intizamını temin etmek ve trafik düzeniyle ilgili tüm hususlarda alınacak önlemleri tespit etmek üzere yasalaşmış olup; söz konusu Kanun ile karayolları araç işletenlerini motorlu aracın faaliyetinden veya işletilmesinden dolayı üçüncü kişilerin uğrayacağı kayıpları telafi etmekle sorumlu tutulmuş ve söz konusu sorumluluğun trafik sigortası ile teminata kavuşturulması öngörülmüştür. Kanun'un 91. maddesinde, zorunlu trafik sigortasının, araç işletenlerin anılan Kanunun 85. maddesinde yer alan sorumluklarını güvenceye almak için yaptırıldığı belirtilmiştir (Bağrıçık, 2016). Bu çerçevede, zorunlu trafik sigortası, bir aracın kullanımı esnasında işletenin, üçüncü şahıslara verebileceği maddi ve bedene ait zararlardan dolayı karşılaşacağı hukuki sorumluluğu güvence altına almaktadır.

Başka bir ifade ile zorunlu trafik sigortası, vergi niteliğinde olmayan, kişilere trafik kazaları nedeniyle taraf oldukları tazminat yükümlülüğüne karşı finansal koruma sağlayan bir özel hukuk işlemidir (Kayıhan, 2016; 254). Dolayısıyla, güvence sağladığı birçok teminatla fertlerin ve toplumun geleceğine yönelik önemli bir işlev üstlenmektedir. Ayrıca, zorunlu trafik sigortası sözleşmesinde çift taraflı (karşılıklı) zorunluluk yer almakta

\footnotetext{
${ }^{1}$ Çalışmada bundan böyle kısaca "zorunlu trafik sigortası” diye ifade edilecektir.

2018 yılı sonu itibariyle sigortacıllk sektöründe üretilen toplam prim üretiminin yaklaşık \%32'si zorunlu trafik sigortasına aittir. Sorumluluk sigortalarındaki toplam payı ise yaklaşık \%86'dır (https://www.tsb.org.tr/resmi-istatistikler.aspx?pageID=909).
} 
olup, işletenler söz konusu trafik poliçesini satın almak zorunda olmalarına karşın anılan sigorta dalında lisans sahibi sigortacılar da bu sigortayı yapmak zorundadırlar (Çelik, 2019).

Zorunlu trafik sigortası ile sağlanan teminatlar; maddi zararlar, tedavi, maluliyet/sürekli sakatlık ve ölüm şeklinde olup, bu teminatların içeriğine ilişkin teknik detaylara 14.05.2015 tarihli ve 29355 say1lı Resmi Gazete yayımlanan Karayolları Motorlu Araçlar Zorunlu Mali Sorumluluk Sigortası Genel Şartlarında yer verilmiştir (Türkiye Sigorta Birliği, 2019).

Maddi zararlar teminatı, kişinin doğrudan malvarlı̆̆ında meydana gelen zararlara, diğer bir ifadeyle malvarlığındaki eksilmelere karşı teminat sağlamaktadır. Sağlık giderleri teminatında, trafik kazası sonucu meydana gelen zarar sebebiyle kazaya karışan kişilerin vücut bütünlügü bozulduğunda, bu kişilerin bedenen eski hale dönmesi amacıyla yapılan tedavi giderleri karşılanmaktadır. Sürekli sakatlık teminatı ile trafik kazası sonucu meydana gelen zarar sebebiyle kazaya karışan kişiler için yapılan sağlık hizmetinden sonra bu kişilerin bedeni durumundaki eksilmenin kalıcı hale gelmesinden itibaren güvence sunulmaktadır. Bu kapsamda, trafik kazası sonucu kişilerin sürekli sakatllğı sonucu bedenindeki eksilme dolayısıyla ekonomik hayata eksik katılımı sebebiyle uğrayacağı maddi kayıplar karşılanmaktadır. Destekten yoksun kalma (ölüm) teminatı ise diğer teminatlardan farklı bir nitelik arz etmekte olup, bu teminatta yansıma hak sahipliği söz konusudur. Söz konusu teminatta hak sahibi kişiler, ölen kişinin desteğinden mahrum kalanlardır (Karasu, 2016; 22).

\section{SERBEST TARIFEYE GEÇIŞ}

Türk sigortacılık sektöründe serbest tarifeye geçiş, diğer bir ifadeyle sektörün rekabetçi bir yapıya kavuşması ilk defa 1990 yılından sonra gerçekleşmiştir. Ancak, söz konusu serbest tarife uygulaması sadece belirli branşlarda (nakliyat, mühendislik, trafik hariç kaza sigortaları, yangın ve zirai sigortalar) söz konusu olmuştur. Zorunlu trafik sigortasında primin kamu otoritesi tarafindan belirlenmesine 2008 yılına kadar devam edilmiş, bu tarihten sonra anılan branşta da serbest tarife uygulamasına geçilmiştir.

Sigortacılık alanında kamu etkinliğinin, fiyat belirleme yerine düzenleme ve denetleme ile sınırlanması, uygun bir rekabet ortamı sağlanarak piyasanın etkinliğinin temini, sigortalının daha kaliteli hizmeti daha uygun fiyata bulmasının sağlanması ve uluslararası mevzuata uyumu amaciyla; 01.07.2008 tarihinden itibaren zorunlu trafik sigortasında primin şirketleri tarafından serbestçe tespitine olanak tanınmıştır.

5684 sayıl1 Sigortac1l1k Kanunu'nun 12. maddesi; "Sigorta tarifeleri, sigortacıllk esasina ve genel kabul görmüş aktüeryal tekniklere uygun olarak sigorta şirketleri tarafindan serbestçe belirlenir" hükmünü amirdir (Türkiye Sigorta Birliği, 2019). Zorunlu trafik sigortasında daha önce kamu otoritesi tarafından belirlenen tarifelerdeki prim fiyatları söz konusu iken, 1 Temmuz 2008'den itibaren ilgili branşta ruhsat sahibi olan ve anılan tarih itibarıyla 31 sigorta şirketinin rekabet ettiği piyasada, primler mezkûr Kanun maddesi hükmü gereğince sigortacılar tarafından sigortacılık temeline ve herkes tarafindan kabul edilmiş aktüeryal tekniklere uygun olarak il ve araç grubu bazında ilgili araç işleteni dikkate alınarak yapılan risk değerlendirmesi sonucunda serbestçe belirlenmiştir (Türkiye Sigorta Birliği, 2019).

Ülkemizde 50 yıldan uzun süredir zorunlu olarak uygulanan zorunlu trafik sigortası tarifelerinin uygulanma sürecine ilişkin bilgilere aşağıda yer verilmiştir.

- 21.12.1959 tarihli ve 7397 sayılı Sigorta Murakabe Kanunu ile 03.06.2007 tarihli ve 5684 sayılı Sigortacılık Kanunu'nda zorunlu sigorta tarifelerinin mülga Hazine Müsteşarlığının bağlı olduğu Bakan tarafindan tespit olunacağı hükme bağlanmıştır.

14.07.2007 tarihli ve 26582 sayılı Resmi Gazetede yayımlanan Karayolları Motorlu Araçlar Zorunlu Mali Sorumluluk Sigortasında Tarife Uygulama Esasları Hakkında Yönetmelik (Yönetmelik) ile Sigortacılık Kanunu'nda yer aldığı üzere, Bakan tarafından tespit edilen zorunlu trafik sigortası tarifelerinin sigorta şirketlerince serbestçe belirlenebileceği hükme bağlanmıştır. Ancak 2007 yılına mahsus olmak kaydıyla, Türkiye Sigorta Birliği (Birlik) tarafindan hazırlanan kurallar 15.07.2007 tarihine kadar onaylanmak üzere mülga Müsteşarlığa gönderilmiş ve 6 aylık süre için $(01.01 .2008$ tarihine kadar) geçerli olmak üzere onaylanmıştır.

- 01.07.2008 tarihinden itibaren, sigorta tarifelerinin sigorta şirketlerince serbestçe tespit edileceği öngörülmüştür.

- 12.04.2017 tarihinden itibaren uygulanmak üzere yürürlüğe konulan "Karayolları Motorlu Araçlar Zorunlu Mali Sorumluluk Sigortası Primlerine İlişkin Genelge" ile zorunlu trafik sigortalarına ilişkin azami prim uygulaması yürürlüğe konmuştur (Türkiye Sigorta Birliği, 2019).

- Hasar frekansı yüksek araç türlerine yönelik yaptırılan poliçelere ilişkin prim ve tazminatın zorunlu trafik sigortası dalında ruhsat sahibi tüm şirketlere dağıtılarak, riskin bazı şirket veya şirketler üzerinde yoğunlaşmasının önüne geçilmesi ve anılan araç türlerinde yer alan araçların sigortasız kalmamasını 
teminen, 11.07.2017 tarihli değişiklikle Yönetmeliğe eklenen geçici 12 nci madde ile "Riskli

Sigortalılar Havuzu" kurulmuştur (11.07.2019 tarih ve 30121 sayılı Resmi Gazete).

Buna göre, zorunlu trafik sigortasında primin belirlenmesine yönelik olarak beş farklı dönem söz konusu olmuştur:

1. Dönem: Kamu otoritesince prim tarifelerinin belirlenmesi

2. Dönem: Birlik tarafindan Rehber Tarifenin hazırlanması

3. Dönem: Serbest tarife uygulaması

4. Dönem: Azami prim uygulamas1

5. Dönem: Havuz uygulaması

Görüleceği üzere, zorunlu trafik sigortasının ülkemizde yaygınlığı ve bilhassa sigortalılar nezdinde oluşan fiyat hassasiyetinden dolayı, bu sigorta branşında prim tutarlarının belirlenmesi usulüne ilişkin önemli değişimler söz konusu olmuştur.

\section{SIGGORTA FIYYATLARINI BELIRLEME YÖNTEMI}

Yukarıda belirtildiği üzere, zorunlu trafik sigortası sisteminin devamı açısından, sigorta fiyatlarının, sigorta şirketlerinin sunduğu güvenceyi karşılayacak, sigortalılar için de kabul edilebilecek düzeyde bulunması çok önemlidir. Aksine bir düzenleme söz konusu değilse, söz konusu sigorta primlerinin sigorta şirketlerince sigorta ilkelerine ve söz konusu sigortanın zorunluluk durumuna uygun şekilde belirlenmesi gerekmektedir.

Sigorta primlerinin belirlenmesinde temel olarak üç kriter bulunmaktadır:

a) Risk primi olarak, gerçekleşecek hasarların ödenmesini sağlayacak bir prim seviyesi tespit edilir.

b) Masraflar, personel giderleri, acente komisyonları ve kâr payı beklentisi risk primine eklenir.

c) Son olarak, vergi ve yasal kesintiler ilave edilerek brüt prim belirlenir.

Risk priminin belirlenmesinde en önemli husus düşük veya yüksek seviyelerde fiyat belirlenmesi olmayıp, hasar sıklığı verileri dikkate alınarak doğru prim seviyesinin tespit edilmesidir. Hasar sıklığı (loss frequency); herhangi bir tehlikeden kaynaklanan hasarların, hangi sıklıkta meydana geldiğini ifade etmekte olup, trafik kazaları, konut olarak kullanılan meskenlerdeki hırsızlık olaylarının sebep olduğu hasarlar, sıklığı yüksek hasar şiddeti (severity) düşük; doğal afet hasarları ise şiddeti yüksek sıklığı düşük niteliktedir (Milli Reasürans T.A.Ş., 2004; 170). Kısaca, hasar sıklığı şirketlerce yazılan poliçeler sonucu ne kadar tazminat ödeneceğinin tahmin edilmesinde kullanılmaktadır. Hasar sıklığı ile hasar şiddetinin çarpımı sonucunda poliçe başına ortalama risk primi hesaplanır. Literatürde hasar şiddeti; bir rizikonun sebep olabileceği doğrudan ve dolaylı hasarların, miktar olarak çok yüksek olabilmesi halidir (Milli Reasürans T.A.Ş., 2004; 255). Hasar şiddeti ile hasar sıklığı arasında ters bir orantı bulunmaktadır.

\section{SERBEST TARIFE SONRASI ZORUNLU TRAFIK SIGORTASI FIYYATLARINDAKI ARTIŞIN NEDENLERI}

Trafik sigortasının mecburi olması, fiyatların makul seviyede olmasını da beraberinde getirmektedir. Primlerin makul seviyelerde olması, sigortalılar için olduğu kadar sigorta sektörü için de önemlidir. Şöyle ki; sektörün sorumluluklarını karşılayamayacak düzeyde (düşük tutarlarda) belirlenen primler zarara uğrayanları zor duruma düşürecek, kişilerin ödeyemeyeceği düzeyde (yüksek tutarlarda) bir fiyatlama ise sistemde poliçesizliğe sebep olacaktır. Bu durum, araç işletilmesi nedeniyle zarara uğrayanları olduğu kadar, bu zararı kendi malvarlığından karşılamak zorunda kalacak işletenleri de olumsuz etkileyecektir. Özellikle 2015 yılının ikinci yarısından sonra bu sigorta dalında gerek sigortalılar gerekse sigorta şirketleri için makul kabul edilecek prim tutarları oluşmamış olup, fiyatlar aşırı yükselmiştir (www.memurlar.net, 2019). Söz konusu fiyat artışlarının temelinde geçmiş yıllardan gelen yapısal sorunların da etki ettiği bilinmektedir (Sarı, 2010; 54).

Sektörde, serbest tarife sistemine geçilmesinden itibaren sert rekabet koşulları dâhilinde oluşan düşük fiyatlama yanlış olduğu kadar, 2015 yılı son çeyreğinden itibaren gözlenen yüksek fiyatlama da uygun bulunmamaktadır. Söz konusu sigorta primlerinin bu tarihten itibaren yükselişe geçmesinin nedenleri çeşitlidir.

İstikrarsız Yargı Kararları: Sorumluluk sigortalarında hak sahiplerinin hasar ve tazminat talepleri, sigorta şirketlerinin sigortalılardan topladıkları primlerden karşılanmakta olup, hak sahipleri ile sigorta şirketleri arasında meydana gelen uyuşmazlıkların yarg1 mercilerine intikal etmesi durumunda yargı mercilerinin karara bağladığı tazminatlar da aynı primlerden karşılanmaktadır. Bu çerçevede poliçenin düzenlenmesi aşamasında teminat kapsamında olmayan tutarlar, zamanaşımı ve uzamış ceza zamanaşımı süreleri de dikkate alınarak yıllar sonra yargı kararları ile teminat kapsamına alınabilmekte, yargı kararları ile hâsıl olan kapsam değişikliğinin emsal oluşturması nedeniyle zincirleme olarak diğer tazminat taleplerini de etkilemekte, geçmişte teminat kapsamında olmadığı gerekçesiyle ödeme yapılmayan hasar dosyalarının 
yeniden açılmasına neden olabilmektedir (Ünan ve Baysal, 2012; 99-110). Dolayısıyla, şirketler açısından dosya başı hasar maliyetleri öngörülen tutarların üzerine çıkmıştır. Şirketler aldığı primlerden çok daha yüksek bir masraf (ölüm ve sakatlık ve maddi tazminatlar) yapmış, sigorta şirketlerinin hasar/prim oranları çok yükselmiş ve şirket bilançolarında zararlar oluşmuştur. Sonuç olarak, sigorta sektörünün yükümlülüklerinde görülen bu artışın temel sebebi son beş yılda önem kazanan yargı kararları olmuştur.

Prim fiyatlarındaki artışa neden olan bir başka unsur, yargı uygulamasında standart bir hasar hesaplama modelinin bulunmamasından dolayı hasar ödemelerinde belirsizliğin oluşmasıdır. Örneğin 2015 yılı öncesinde, kamu otoritesi tarafından yayımlanmış ve bedeni hasar tazminatlarına esas teşkil eden kriterler mevcut olmasına karşın, söz konusu kriterlerin yargı mercileri tarafından dikkate alınmadığı gözlenmiştir (Türkiye Sigorta Birliği, 2019). Dolayısıyla, pratik uygulamada tazminat hesaplama yöntemleri arasında farklılıklar oluşmuş ve şirketler özellikle yargı kararlarının sonucunda daha yüksek tazminat miktarlarıyla karşıllaşmıştır.

İki Sigorta Şirketinin Mali Bünye Zâfiyetine Düşmesi: 2015 y1lında mali bünye zafiyeti sebebiyle iki sigorta şirketinin faaliyetleri 5684 sayılı Sigortacılık Kanunu hükümleri çerçevesinde mülga Müsteşarlık tarafından sonlandırılmış ve Güvence Hesabına devredilmiştir (Hazine ve Maliye Bakanlığı, 2019). Bankacılık sektöründeki Tasarruf Mevduat Sigortası Fonu'nun bir nevi karşılığı ve eski ismi garanti fonu olan Güvence Hesabı; sigorta şirketlerinin iflas ve tasfiye hallerine ve sigortasızlı durumlarına karşı güvence sağlayan bir hesaptır (www.guvencehesabi.org.tr/, 2019). Bunun sonucu olarak, sigorta şirketlerinde risk algılamas1 yükselerek yükümlülüklerde görülen artışın sektör mali bünyesine olan etkisi öz kaynak ilavesi yanında sigorta fiyatlarının yükselmesine neden olmuştur.

Döviz Kurlarındaki Yükseliş: 2015 yılında gerek dış gerek iç ekonomik gelişmelere bağlı olarak Türkiye ekonomisinde döviz kurları yükselmeye başlamıştır. Dolayısıyla, fiyatların yükselmesine dayanak teşkil eden başka bir sebep, döviz kurundaki aşırı dalgalanmaya bağlı olarak otomobil yedek parça fiyatlarında artışların meydana gelmesidir.

Bedeni Hasar Tazminatlarındaki Yükseliş: Fiyatların yükselmesindeki en önemli nedenlerden biri bedeni hasar tazminat taleplerindeki ve böylece sigorta şirketlerinin maliyetlerindeki yükseliştir. Son y1llarda şirketin bedeni hasar tazminatlarında özellikle sürekli sakatlık tazminatındaki artışlar nedeniyle yine şirket maliyetlerinde artışlar olmuş ve söz konusu maliyetler de sektörde prim artı̧̧ı olarak yansımıştır.

Değer Kaybı Talepleri: Sigorta şirketlerinin maddi hasar taleplerindeki bir başka maliyet unsuru değer kaybı olmuştur. Nitekim 2015 yılında kamu otoritesi tarafindan bir düzenleme yapılarak, sigortalı tarafindan değer kaybı talebinin olması halinde zorunlu olarak sigorta şirketleri eksper tayin ederek değer kaybının hesaplanması ve sigortalıya ödenmesi hükme bağlanmıştır. Dolayısıyla sigorta şirketleri açısından dosya maliyetlerinde maddi tazminatlar artmış ve buna bağlı olarak değer kaybı taleplerini de prim fiyatlarına yansitmışlardır (www.sigortam.net, 2019).

Aracı Kişilerin Rolü: Hak sahiplerinden vekâletname veya temlikname almak suretiyle hak sahiplerinin tazminat haklarını takip eden aracı kişilerin sayısının artması ve tazminatın önemli bir kısmının bu kişilere ödenmesi da sigorta fiyatlarının yükselmesine neden olmuştur (Kantar, 2013).

Sonuç olarak, zorunlu trafik sigortası poliçe düzenlenmesi sırasında sigorta teminatı kapsamında bulunmayan taleplerin mahkeme kararları ile kapsama alınması, uygulamada teminat içeriği ve tazminat hesaplama yöntemlerine ilişkin bilirkişi ve yargı mercilerince farklı yorumlar getirilmesi (özellikle geriye etkili yargı içtihatları gibi ) sonucu standartların oluşturulamaması, tazminat taleplerini takip eden aracı kişilerin sayısının artması, sürekli sakatlık tazminatı seviyelerinin yükselmesi, değer kaybı, yedek parça fiyatlarındaki artış ve mali bünye zafiyeti nedeniyle iki şirketin Güvence Hesabına devredilmesi gibi nedenler sigorta şirketlerinin belirsizlikle karşılaşmasına, primlerin doğru hesaplanamamasına, şirketlerin finansal durumlarının bozulmasına ve zarar ederek aşırı yükümlülüklerle karşı karşıya kalmalarına yol açmış, böylece sigorta fiyatlarında artışlar gerçekleşmiştir. Aşırı fiyat artışlarının nedenlerinden biri olan teknik kâr/zarar durumları aşağıdaki tabloda gösterilmiştir. 
Tablo 1: Zorunlu Trafik Sigortasında Yıllar İtibariyle Teknik Kâr/Zarar Durumu

\begin{tabular}{|c|c|c|c|c|c|c|c|c|c|c|c|c|}
\hline YIL & 2007 & 2008 & 2009 & 2010 & 2011 & 2012 & 2013 & 2014 & 2015 & 2016 & 2017 & 2018 \\
\hline $\begin{array}{c}\text { PRIM } \\
\text { (Milyon) }\end{array}$ & 1.583 & 1.815 & 1.972 & 2.305 & 2.700 & 3.600 & 4.966 & 5.073 & 6.962 & 12.467 & 12.498 & 14.490 \\
\hline $\begin{array}{c}\text { TEKNIK } \\
\text { KÂR/ZARAR } \\
\text { (Milyon) }\end{array}$ & -245 & -467 & -293 & -585 & -462 & -1.285 & -655 & -885 & -2.677 & -325 & -515 & -692 \\
\hline $\begin{array}{c}\text { TEKNIK } \\
\text { KÂR/ZARAR } \\
\text { ORANI }\end{array}$ & $-15 \%$ & $-26 \%$ & $-15 \%$ & $-25 \%$ & $-17 \%$ & $-36 \%$ & $-13 \%$ & $-17 \%$ & $-38 \%$ & $-3 \%$ & $-4 \%$ & $-5 \%$ \\
\hline
\end{tabular}

Kaynak: https://www.tsb.org.tr/resmi-istatistikler.aspx?pageID=909; Erişim Tarihi 08.03.2019)

Tablo 1'den görüleceği üzere, son on iki yılda zorunlu trafik sigortasında sürekli olarak teknik zarar oluşmuştur. Havuz öncesi durum ve fiyatların yükselişinin başladığı tarih olan 2015 yılında teknik zarar seviyesi zirveye ulaşmıştır. Daha sonra sektör tarafından söz konusu zararın sürdürülemeyeceği anlaşılmış ve sigorta fiyatlarında aşırı yükseliş olmuştur. Dolayısıyla 2016 yılında zarar azalarak, Teknik Zarar oranı $\% 38$ 'den \%3'e gerilemiştir. Havuzun kurulduğu yıl olan 2017 ve sonraki yıllarda teknik zarar oranları sırasıyla $\% 4$ ve $\% 5$ olarak gerçekleşmiştir. Görüleceği üzere 2015 yılı öncesine göre teknik zarar oranları düşük seviyelerde olmakla birlikte her y1 \%1 oranında artmaktadır.

\section{ZORUNLU TRAFÍK SIGGORTASINDA AŞIRI SEVIYYELERDE OLUŞAN PRIMM FIYATLARINA KARŞI ALINAN ÖNLEMLER}

2015 yılının Haziran ayından sonra zorunlu trafik sigortası fiyatlarında oluşan artış toplumun büyük bir kısmını etkilemiş ve sigortalıların zorunlu trafik sigortası primini ödemesini zorlaştırarak ilgili kamu otoritesine yöneltilen şikâyetlerin sayısında artışa yol açmıştır.

Söz konusu fiyat yükselişlerine karşı kamu otoritesi tarafından çeşitli önlemler alınmıştır. 2918 sayılı Kanun ve ilgili mevzuatta değişiklik yapılmak suretiyle zorunlu trafik sigortalarında fiyatlamada istikrarı bozan yapısal sorunlara karşı yasal güvence sağlanmaya çalışılmıştır.

İlk aşamada, bazı araç türlerinde sigorta şirketleri tarafından zorunlu trafik sigortalarına ilişkin aşırı yüksek tutarlarda prim talep edildiğine ilişkin bilgilerin intikal ettirilmesi üzerine, yetkili otorite olan Türkiye Sigorta Birliği ve Türkiye Odalar ve Borsalar Birliğini muhatap 27.10.2015 tarihli yazıda (Türkiye Sigorta Birliği, 2019); Yönetmeliğin 16'ncı maddesine dayanarak, sigorta şirketlerinin zorunlu trafik sigortası yapmaktan kaçınmasını önlemek amacıyla; kamyon, kamyonet, minibüs, otobüs (sürücü dâhil 18-30 koltuk), otobüs (sürücü dâhil 31 ve üstü koltuk) ve taksi araç türleri için 28.10.2015 tarihinden sonraki düzenlenecek poliçelerle ilgili olarak azami brüt prim tutarları belirlemiştir.

Buna ilave olarak, yine kamu otoritesi tarafından 2013/11 Sayılı Genelgede Değiş̧iklik Yapılmasına İlişkin 28.12.2015 tarihli ve 2015/55 sayılı mülga Genelgeyle (Türkiye Sigorta Birliği, 2019); gerek sigortacılık sektöründe rekabetçi ortamın geliştirilmesi gerekse piyasadaki güncel prim seviyelerinin tüketiciye şeffaf bir şekilde sunulabilmesi amaciyla Sigorta Bilgi ve Gözetim Merkezi web sitesinde (www.sbm.org.tr) oluşturulan teklif ekranı üzerinden kimlik numarası ve plaka bilgileri girilerek zorunlu trafik sigortası poliçesi düzenleyen tüm sigorta şirketlerinin fiyat tekliflerinin karşılaştırmalı olarak görüntülenmesi sağlanmıştır.

Bununla birlikte, Rekabet Kurumu tarafindan 28.03.2016 tarihinde rekabeti engelleyici, kısitlayıc1, bozucu veya uyumlu eylem faaliyetleri yaptığı (ortak hareket ettiği) ve böylece aşırı yüksek fiyat uyguladıkları iddiasıyla ilgili olarak anılan sigortada faaliyet gösteren sigorta şirketleri hakkında soruşturma açılmıştır (www.rekabet.gov.tr, 2019).

Kamu otoritesi tarafından 2918 sayılı Kanun'da 26.04.2016 tarihinde yapılan değişiklik ${ }^{3}$ marifetiyle, zorunlu trafik sigortası teminat içeriğinin sigortacılık ilkelerine ve değişen şartlarla uyumlandırılması, ayrıca trafik sigortası primlerinde yaşanan artışı önüne geçilmesine yönelik olarak fiyatlamada istikrarı bozan ve yargı kararlarından kaynaklanan yapısal sorunlara karşı güvence sağlanması amaçlanmıştır.

Alınan bu önlemlere rağmen sigorta fiyatlarında makul oranlara ulaşılamamış ve kamu otoritesi tarafindan daha köklü ve kısa vadede çözüm sağlayacak uygulamaların getirilmesine yönelik çalışmalar başlatılmıştır.

${ }^{3}$ 26.04.2016 tarihli ve 29695 sayılı Resmi Gazetede yayımlanan 14.04.2016 tarihli ve 6704 sayılı “65 Yaşını Doldurmuş Muhtaç, Güçsüz ve Kimsesiz Türk Vatandaşlarına Aylık Bağlanması Hakkında Kanun ile Bazı Kanun ve Kanun Hükmünde Kararnamelerde Değişiklik Yapılmasına Dair Kanun”. 


\subsection{Kişi Temelli Poliçe}

Kamu otoritesi tarafından çalışılan ilk uygulama kişi temelli poliçe olmuştur. Nitekim zorunlu trafik sigortasında prim seviyelerinin arzu edilen tutarlara gerilemesini teminen gerek mülga Hazine Müsteşarlığı gerekse Türkiye Sigorta Birliği tarafından konuya ilişkin çalışma başlatılmıştır (Özkap, 2016). Söz konusu çalışmanın ana amacı, poliçenin fiyatlandırılmasında ve riskin ölçülmesinde sürücü odaklı bir yaklaşımla temel ölçüt olarak araç yerine kişinin temel alınmasının sağlanmasıdır.

Nitekim bu çalışma ile başta İngiltere ve Almanya olmak üzere Avrupa'nın çeşitli ülkelerinde ve Amerika Birleşik Devletleri'nde (ABD) kullanılan kişi temelli poliçelerde olduğu gibi ülkemizde de zorunlu trafik sigortası poliçelerinin kişilerin/sigortalıların sürüş davranışlarına ve performansına (hasar geçmişi, yaş, cinsiyet, meslek, ehliyet ve ceza puanı vb.) göre fiyatlanması amaçlanmaktadır.

Motorlu araç sigortalarında sigortalıların kişisel bazda sigortalanmasının sigorta tekniği açısından daha doğru bir uygulama olduğu düşünülmektedir. Zira bu sistemde riskli sürücüler yüksek, iyi sürücüler ise düşük tutarlarda prim ödeyecek ve böylece daha adil bir yöntem uygulanmış olacaktır.

Ülkemizde fiyatların belirlendiği serbest dönemde sigorta şirketleri tarafından nispeten kişisel bilgiler kullanılmış olsa da kişinin ehliyetine bağlı olarak ceza puanı, ehliyet puanı ve bunun gibi bilgiler dikkate alınmamış, dolayısıyla "iyi-kötü" sürücü ayrımı tam olarak ortaya konamamıştır. Dolayısıyla kişi temelli poliçede, sadece o kişiye özgü kişisel verilerin de dikkate alınarak, hatta kişinin sahip olduğu aracın başkası (eş ve çocuklar) tarafından kullanılabilecek olması durumunun da fiyatlanması söz konusudur. Diğer bir ifadeyle, bu sistem araca bağlı olarak oluşturulacak sürücü listesinde aracı kullanacak kişilerin belirlenerek, bu kişilerin kişisel verilerinin dikkate alınması suretiyle poliçenin oluşturulduğu bir sistemdir. Nitekim, yurtdışı uygulamalarında özellikle kısa süreli araç kiralama işlemlerinde kişi temelli poliçe dikkate alınarak fiyatlama yapıldığı, ABD'de olduğu üzere kişilerin kendilerine ait araçları olmasa dahi kişisel bilgileri dikkate alınarak zorunlu trafik poliçesine sahip olabildiği bilinmektedir.

Böyle bir uygulama ile sürücülerin daha dikkatli araç kullanması sağlanarak ve sorumluluk bilinci ve farkındalıkları artırılarak, daha adil bir fiyatlamanın yapılmasında ve kazaların azalmasında önemli bir faktör olacağı düşünülmektedir. Başka bir ifadeyle, bahse konu uygulamanın sonucunda sigortalıların sürüş davranışları olumlu yönde etkilenerek, sorumlulukları artacak, daha iyi sürücü konumundaki insanlar ödüllendirilecek, riskli sürücüler ise tersi yönde etkilenecektir.

Ne var ki, kişi temelli poliçe çalışmaları yürütülürken sorunlar devam etmiş ve kamu otoritesi tarafindan fiyatlara gecikmeksizin müdahale edilmesi kararlaştırılmıştır. Diğer bir ifadeyle, fiyat sorununa çözüm olarak ilk aşamada tavan fiyat uygulaması getirilmiştir.

\subsection{Tavan Fiyat Uygulaması}

Fiyat istikrarını bozan yapısal problemlerin çözümüne yönelik ilgili mevzuat çalışmalarının gerçekleştirilmesi ve rekabeti artırmaya yönelik alınan tedbirlerin alınmasına karşın prim seviyelerinin istenen düzeylere gerilememesi, zorunlu trafik sigortalarında azami prim tutarlarının belirlenmesine yönelik müdahaleyi kaçınılmaz kılmış, diğer bir ifadeyle kamu otoritesi tarafından tavan fiyat uygulamasına geçilmiştir (Tunç ve Akpınar, 2018; 227). Bazı sigorta şirketlerinin riskli gruplarda yer alan sigortalılar için poliçe düzenlemekten kaçınması ve sigortalıların zorunlu olan bir sigortayı temin edememesi de bu uygulamanın kısa sürede getirilmesinde etkili olmuştur.

10.04.2017 tarihli ve 2017/1 say1lı "Karayolları Motorlu Araçlar Zorunlu Mali Sorumluluk Sigortas1 Primlerine İlişkin Genelge" ile (Türkiye Sigorta Birliği, 2019) araç grubu, basamak ve il grupları bazında zorunlu trafik sigortalarına ilişkin azami primler belirlenmiştir. Bu uygulama ile trafik sigortası primlerinin daha makul seviyelere çekilmesi büyük ölçüde sağlanmıştır.

Söz konusu Genelgede esas itibariyle, tüm araç gruplarına yönelik olarak araç grubu bazında orta basamak denilen dördüncü basamak ${ }^{4}$ için azami tavan fiyatlar, diğer basamaklar için de sürücülerin hasar deneyimine dayanan prim indirim/artırım oranları, iller bazında indirim/artırım oranları, aracı komisyon tutarları, prim tutarının hesaplanması, prim tutarlarının aylık olarak ne oranda artırılacağı gibi hususlar düzenlenmek suretiyle, sigorta şirketlerinin belirleyebileceği sigorta primlerinin belirli tutarları aşamayacağı hükme bağlanmıştır (Doğan, 2017).

\footnotetext{
${ }^{4}$ Zorunlu trafik sigortasının poliçelendirilmesinde ve fiyatlamasında basamak yöntemi uygulanmakta olup, toplam 7 basamak mevcuttur. İlk defa poliçe yaptıracaklar baz basamak denilen 4. Basamaktan giriş yapmakta olup, herhangi bir tazminat ödemesi yapılmadığında bir üst basamağa, hasar sonrasında tazminat ödemesi söz konusu olduğunda ise her tazminat ödemesi için prim oranlarının daha yüksek olduğu bir alt basamağa düşmektedir. 1,2 ve 3 . basamaklar riskli (sürprimli veya artırımlı) basamaklar, 5,6 ve 7. basamaklar indirimli basamaklardır. Aynı yıl içerisinde birden fazla hasar yapıldığında hasar sayısı kadar basamak, sakatlanma ve destekten yoksun kalma hasarı oluştuğunda ise iki basamak birden düşülmektedir. İndirim ise yılda bir defa uygulanmaktadır (Baykal ve Bülbül, 2016; 19).
} 
Dolayısıyla aşırı yüksek sigorta fiyatları kamu otoritesi tarafından tavan fiyat uygulamasıyla aşağı çekilerek indirim sağlanması amaçlanmıştır. Nitekim, kamu otoritesinin en yetkili makamı olan ilgili Bakan tarafından trafik sigortasında tüm Türkiye'de ortalama \%30 indirim olacağı, riskli araç gruplarında \%28, düşük riskli gruplarda ise \%26'lık bir indirim öngördükleri belirtilmiştir (www.ensonhaber.com, 2019).

\subsection{Riskli Sigortalılar Havuzu}

Tavan fiyat uygulaması sonrası, bazı sigorta şirketlerinin azami prim uygulaması sonrasında özellikle hasar frekansı yüksek basamak ve/veya araç grupları için poliçe düzenlemekten kaçındığı görülmüştür. Bu sorunun çözümü amacıyla, hasar sıklığı yüksek basamak ve/veya araç grupları temelinde düzenlenen poliçeler için prim ve tazminatların trafik sigortası branşında ruhsat sahibi tüm şirketlere dağıtılması suretiyle, riskin bazı şirket veya şirketler üzerinde yoğunlaşmasının engellenmesi ve bahsi geçen gruplarda yer alan araçların sigortasız kalmamasını teminen, 11.07.2017 tarihli değişiklikle Yönetmeliğe eklenen geçici 12 nci madde ile "Riskli Sigortalılar Havuzu" kurulmuştur (Temur, 2018; 323). Nitekim sigorta havuzları; maliyetleri ve potansiyel riskleri paylaşmak adına sigorta şirketlerinin bir araya gelerek yüksek riskli ve düşük riskli sigortalılara belirli branşlarda teminat sunmak üzere oluşturulmakta ve söz konusu riskler havuz sisteminde sigorta şirketleri arasında belirli kurallara göre dağıtılmaktadır (Sisk, 2018).

Havuzun çalışma esasları anılan Yönetmelik ekinde düzenlenmiştir. Söz konusu esaslara göre, Zorunlu trafik sigortasında ruhsatı bulunan tüm şirketler havuza zorunlu olarak dâhil olacak, bir başka ifadeyle havuzun doğal üyesi olacaktır. Havuzun yönetimi Türkiye Motorlu Taşıt Bürosu (TMTB) tarafından yürütülecektir.

Özellikle havuzun isminden de anlaşılacağı üzere, riskli gruptaki araçlar için oluşturulan ve bu riskin havuzdaki tüm şirketlere dağıtılmasını öngören yapıda; 1 ., 2. ve 3. basamaklarda yer alan tüm araç grupları ile 4., 5., 6., ve 7. basamaklarda yer alan taksi, minibüs, otobüs, kamyon ve çekici türündeki araç grupları Havuz kapsamındadır. Risksiz grup olan 5., 6., ve 7. basamaklarda bazı araç grupları için \%10, \%20 veya \%30 şeklinde indirim oranları, ayrıca \%8 seviyesinde aracı komisyonu oranı belirlenmiştir. Ancak, belirtmek gerekir ki ülkemizde yaygınlığı fazla olan, diğer bir ifadeyle araç sayısının yoğunlaştığg grup olan 4., 5., 6. ve 7. basamaklardaki otomobil araç grubu havuz kapsamında yer almamaktadır. Bu gruba kamyonet, traktör, motosiklet ve iş makineleri de dâhildir. Zira bu havuzun amacı riskli gruplar için olup, hasar sıklığ1 ve şiddeti daha düşük seviyelerde olan anılan araç grupları için havuz uygulaması söz konusu değildir. Bulunulan basamak ve araç grubuna göre havuza dâhil olup olunmaması söz konusu olacaktır. Havuz kapsamına dâhil olunması durumunda indirim oranları gerilemekte, fiyatlar bir miktar artmaktadır.

Tablo 2: Havuz Kapsamındaki Araç Türleri

\begin{tabular}{|l|c|c|c|c|c|c|c|}
\hline ARAÇ GRUPLARI & \multicolumn{7}{|c|}{ BASAMAKLAR } \\
\hline & $\mathbf{1}$ & $\mathbf{2}$ & $\mathbf{3}$ & $\mathbf{4}$ & $\mathbf{5}$ & $\mathbf{6}$ & $\mathbf{7}$ \\
\hline Otomobil & $*$ & $*$ & $*$ & & & & \\
\hline Taksi & $*$ & $*$ & $*$ & $*$ & $*$ & $*$ & $*$ \\
\hline Minibüs (10-17 koltuk) & $*$ & $*$ & $*$ & $*$ & $*$ & $*$ & $*$ \\
\hline Otobüs (18-30 koltuk) & $*$ & $*$ & $*$ & $*$ & $*$ & $*$ & $*$ \\
\hline Otobüs (31 üstü koltuk) & $*$ & $*$ & $*$ & $*$ & $*$ & $*$ & $*$ \\
\hline Kamyon & $*$ & $*$ & $*$ & $*$ & $*$ & $*$ & $*$ \\
\hline Çekici & $*$ & $*$ & $*$ & $*$ & $*$ & $*$ & $*$ \\
\hline Kamyonet & $*$ & $*$ & $*$ & & & & \\
\hline Motorsiklet & $*$ & $*$ & $*$ & & & & \\
\hline Traktör & $*$ & $*$ & $*$ & & & & \\
\hline İŞ Makinesi & $*$ & $*$ & $*$ & & & & \\
\hline Özel Amaçli Araç & $*$ & $*$ & $*$ & & & & \\
\hline Römork & $*$ & $*$ & $*$ & & & & \\
\hline Tanker & $*$ & $*$ & $*$ & & & & \\
\hline Tarım Makinesi & $*$ & $*$ & $*$ & & & & \\
\hline
\end{tabular}

* işaretli yerler riskli havuz kapsamındaki araç gruplarını göstermektedir.

Havuz kapsamında toplanan primler ve yapılacak tazminat ödemelerinin paylaşımında iki aşamalı bir durum söz konusudur:

Havuzda toplanan primler ve yapılacak tazminat ödemelerinin \% 50'lik kısmı tüm üyeler arasında eşit oranda paylaştırılmaktadır. Örneğin, zorunlu trafik sigortası branşında 30 sigorta şirketinin faaliyet 
göstermesi durumunda Havuza dâhil her bir üyenin \% 50’lik kısımdan hissesi \% 1.66 oranında olacaktır.

- Diğer \% 50 lik pay ise sigorta şirketlerinin son 3 yıllık dönemde Trafik Sigortası üretimindeki pazar payına (prim üretimi) göre paylaştırılmaktadır. Örneğin, son üç yıllık dönemde prim üretimindeki payı ortalama \%10 seviyesinde olan bir sigorta şirketine, bahse konu \% 50'lik kısmın \%5'lik bölümü devredilmektedir.

Yukarıda sunulan iki duruma göre yapılan hesaplama, ilgili üyenin bir sonraki yılda düzenlenecek poliçeler bakımından havuz payını oluşturmakta üye şirketlerin havuzdan alacağı prim ve ödenen hasar tazminat miktarına hangi oranda katılacağını tespit etmektedir. Dolayısıyla prim ve tazminat tutarları sigorta şirketlerine daha homojen bir şekilde dağıtılmaktadır.

Diğer taraftan, Havuzun üyeler bakımından borç/alacak ilişkisi ise şu şekilde yürümektedir:

- Sigorta şirketi her ay düzenlediği poliçe priminin \% 76'lık kısmını (SGK, Güvence Hesabı, Komisyon, Genel Gider paylarını düşerek) havuza devretmekte; devir sırasında o ay içinde ödemiş olduğu hasar tazminatlarının tutarını havuza iletmektedir.

- Aylık dönemler halinde havuzda toplanan \% 76’lık prim ve her bir üyenin o ay içinde Riskli Sigortalılar Havuzunu ilgilendiren poliçeler için ödediği tazminatlar; bu defa, daha önce oluşumu anlatılan havuz paylarına göre üye şirketlere dağıtılmaktadır.

Yapılan bu dağıtım sonucunda üyelerin bir kısmı havuza borçlu, geri kalan diğer kısmı ise havuzdan alacaklı hale gelmektedir.

Yukarıda belirtildiği üzere, Riskli Sigortalılar Havuzunun kuruluş ve işleyiş kuralları gereği Havuzun hesap yönetimi TMTB'ye verilmiş olup, TMTB her ayın sonunda ürettiği hesap belgelerine istinaden üyeler arasındaki borç alacak hesabını yönetmektedir.

Mevcut durum itibariyle Havuza konu olan araçların sahipleri sigorta teminatı bulmada zorluk yaşamamakta, sigorta şirketleri adı geçen araç grupları bakımından poliçe düzenlemekten kaçınmamaktadır.

Zorunlu trafik sigortasında Havuz ve havuz öncesi durumu gösteren önemli sigortacılık verileri aşağıda yer almaktadir.

Tablo 3: Havuza İlişkin Veriler

\begin{tabular}{|c|c|c|c|c|c|c|}
\hline YIL & $\begin{array}{l}\text { TOPLAM } \\
\text { PRİM } \\
\text { (Milyon TL) }\end{array}$ & $\begin{array}{l}\text { POLİÇE } \\
\text { ADEDİ } \\
\text { (Milyon) }\end{array}$ & $\begin{array}{l}\text { ORTALAMA } \\
\text { POLİÇE } \\
\text { FIYATI (TL) }\end{array}$ & $\begin{array}{c}\text { TÜKETİCI } \\
\text { FİYAT } \\
\text { ENDEKSI } \\
\text { ORTALAMASI }\end{array}$ & $\begin{array}{l}\text { ORTALAMA } \\
\text { POLİÇE FIYATI } \\
\text { (TL, 2018 YILI } \\
\text { FİYATI İLE) }\end{array}$ & $\begin{array}{l}\text { SİGORTASIZLIK } \\
\text { ORANI }(\%)\end{array}$ \\
\hline \multicolumn{7}{|c|}{ HAVUZ ÖNCESİ DURUMU } \\
\hline 2007 & 1.583 & 10,4 & 169 & 140,0 & 438 & 25,15 \\
\hline 2008 & 1.815 & 10,4 & 190 & 154,7 & 446 & 25,39 \\
\hline 2009 & 1.972 & 10,8 & 201 & 164,3 & 444 & 25 \\
\hline 2010 & 2.305 & 11,7 & 215 & 178,4 & 438 & 23,34 \\
\hline 2011 & 2.700 & 13,1 & 223 & 190,0 & 426 & 22,11 \\
\hline 2012 & 3.600 & 13,9 & 283 & 206,8 & 497 & 22,55 \\
\hline 2013 & 4.966 & 14,6 & 380 & 222,3 & 621 & 22,34 \\
\hline 2014 & 5.073 & 15,9 & 348 & 242,0 & 522 & 19,56 \\
\hline 2015 & 6.962 & 16,2 & 469 & 260,6 & 654 & 20,3 \\
\hline 2016 & 12.467 & 16,5 & 832 & 280,9 & 1076 & 23,16 \\
\hline \multicolumn{7}{|c|}{ HAVUZ SONRASI DURUM } \\
\hline 2017 & 12.498 & 17,5 & 698 & 312,1 & 812 & 21,98 \\
\hline 2018 & 14.490 & 18,7 & 754 & 363,1 & 754 & 22,38 \\
\hline
\end{tabular}

Kaynak: (https://www.tsb.org.tr/resmi-istatistikler.aspx?pageID=909; http://tuik.gov.tr/UstMenu.do?metod=temelist, Erişim Tarihi 01.03.2019) 
Yukarıdaki tabloda ortalama poliçe fiyatları hem nominal hem de reel olarak ${ }^{5}$ gösterilmiştir. Zorunlu trafik sigortasında prim üretimi ve sigorta fiyatları bakımından 2015 yılına kadar olağan artış seyri devam etmiş ancak 2015 yılının ikinci yarısından itibaren bir anda sıçrama yaşanmıştır. Örneğin 2015 yılında reel olarak 654 TL olan fiyat bir sonraki yılda yaklaşı \%65 artarak 1.076 TL olmuştur. Buna bağlı olarak toplam prim üretimi de aynı şekilde artmıştır. 2016 yılında yapılan yasal değişiklik ve kamu otoritesinin 2017 yılında uyguladığı tavan fiyat ve Riskli Sigortalılar Havuzu uygulamaları sonrası sigorta fiyatı reel olarak 1.076 TL'den 812 TL'ye düşmüş, toplam prim üretiminde ise bu tarihlerde önemli bir değişiklik yaşanmamış, ancak 2018 yılı sonunda prim üretimi yükselmiştir. Sigortasızlık oranı ise artan fiyatlar üzerine $2015(\% 20,30)$ ve $2016(\% 23,16)$ yıllarında yükselmiş, yapılan müdahaleler sonrası ise 2017 yılında $(\% 21,98)$ düşmüştür. Bu nedenle, gerek toplam prim üretimi gerekse sigortasızlık oranı fiyata olan duyarlılığından dolayı hızlı bir şekilde etkilenmiştir. Bununla birlikte, 2007 y1lında 169 TL olan ortalama fiyat 2018 y1lı sonu itibariyle yaklaşık 4,5 kat artarak $754 \mathrm{TL}$; toplam prim üretimi ise yaklaş1k 9 kat artarak 2018 y1l sonunda 14,5 milyar TL olarak gerçekleşmiştir. Reel fiyatlarda ise 2007-2012 yılları arasında nispeten durağan seyir devam etmiş, sonraki yıllarda ise yükselişe geçmiştir. Poliçe adetlerindeki artış daha çok trafiğe kayıtlı araç sayısındaki artışa bağlı olarak yıllar içinde artmış, ancak sigorta fiyatlarındaki aşırı yükseklik artış hızını düşürmüştür.

Ortalama poliçe fiyatlarındaki reel değişim şekilsel olarak aşağıda gösterilmiştir.

Şekil 1: Ortalama Poliçe Fiyatı (2018 yılı fiyatı ile)

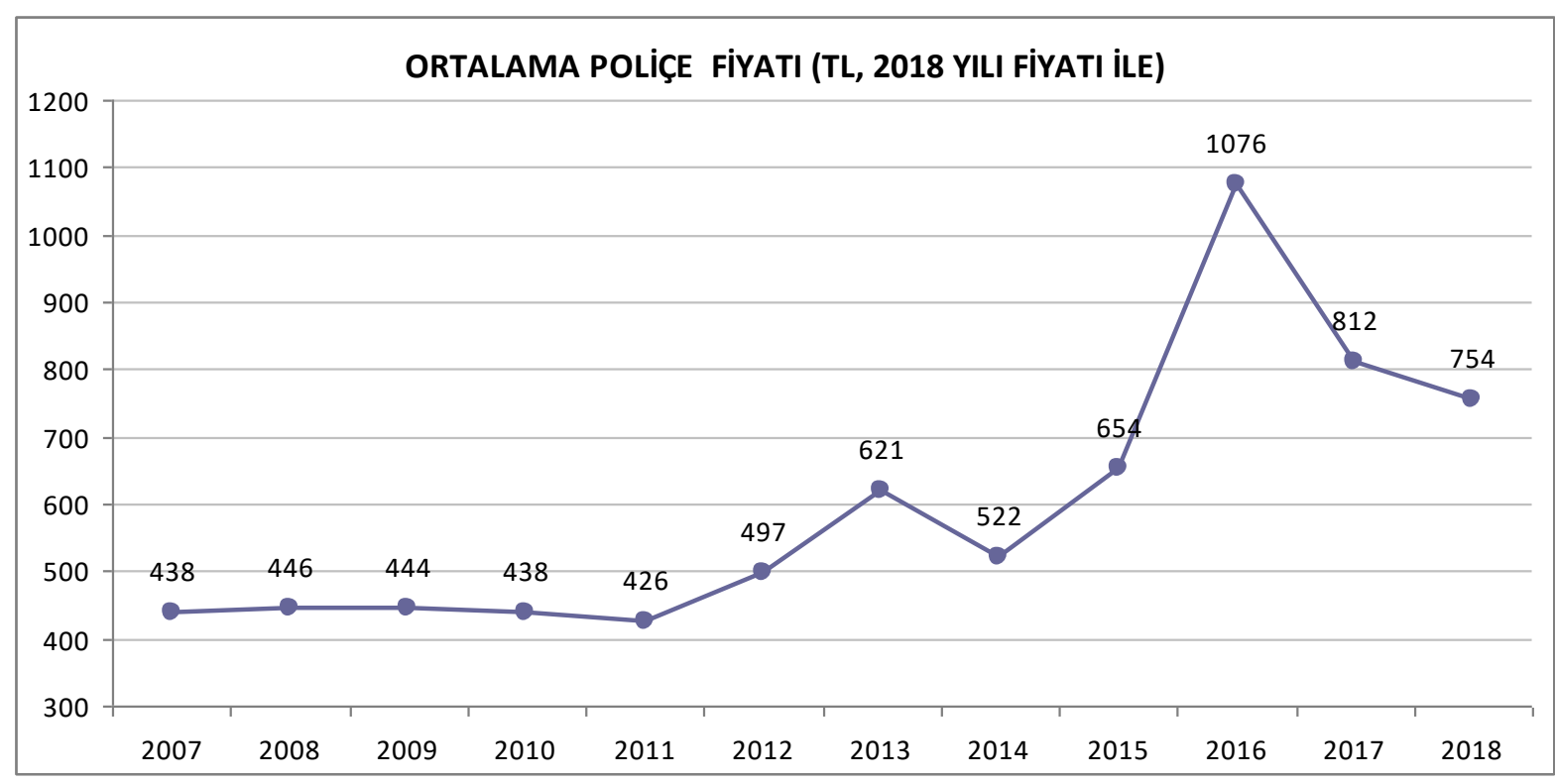

\section{TRAFİK SİGORTASINDA HAVUZ UYGULAMASINA İLISŞKINN ÜLKE ÖRNEKLERİ}

Dünya genelinde zorunlu trafik sigortasında havuz ve havuz benzeri modeller bulunmakla birlikte, bu sistemler ülkemizdeki uygulamadan bazı farklılık göstermektedir. Diğer ülke örneklerinde, özellikle sigorta şirketleri tarafından herhangi bir nedenle sigortalanmayan risklere yönelik özel piyasa, kurum, büro, plan ve/veya havuzların kurulduğu görülmektedir.

Örneğin, Amerika Birleşik Devletleri (ABD)'nde zorunlu trafik sigortası dâhil tüm branşlarda yüksek riskli sigortalılar için sigorta şirketlerince teminat sunulmaması durumunda, ilgili eyaletin yetkili otoritesi tarafından yönetilen ve "artık piyasa" (residual market) olarak adlandırılan özel bir piyasada, söz konusu sigortalılara yönelik teminat sunulmaktadır. Nitekim ABD'de Florida, Missouri, Hawaii ve Michigan eyaletlerinde zorunlu trafik sigortalarında yüksek riskli gruplar için havuz benzeri bir uygulama olan Müşterek Sigorta Birlikleri (Joint Underwriting Associations) oluşturulmuştur. Bu kapsamda düzenlenen poliçeler sigorta şirketlerine pazar payları nispetinde dağıtılmakta, hasar ve tazminat ödemelerine ilişkin tutarlar da belirli kurallar dâhilinde şirketlere paylaştırılmaktadır (Insurance Information Institue, 2019).

\footnotetext{
${ }^{5}$ Tabloda, ortalama poliçe fiyatları nominal olarak, ayrıca 2018 yılı fiyat seviyesi esas alınarak sabit fiyatlarla gösterilmiş̧ir. Ortalama poliçe fiyatlarının sabit fiyatlarla belirlenmesinde; yıllar itibarıyla tüketici fiyat endeksinin aylık değerlerinin ortalaması kullanılmıştır. Örneğin 2007 yılındaki 169 TL olan nominal fiyat, o yılın enflasyon endeksi olan 140'a bölünmüş ve çıkan sonuç 2018 yılı enflasyon endeksi 363,1 ile çarpılarak 438 TL'lik sabit fiyat (2018 yılı fiyatlarıyla) rakamına ulaşılmıştır.
} 
Ayrica; zorunlu trafik sigortasiyla ilgili olarak,

- Fransa'da riskli sigortalılar için Fiyatlandırma Kontrol Bürosu tarafından belirli bir fiyat tarifesi uygulanmaktadır (International Actuarial of Assocition, 2019).

- İtalya ve Romanya'da prim artışlarının kontrol edilmesi için tavan fiyat uygulaması getirilmiştir (Price Waterhouse Coopers, 2016).

- Belçika'da sigortalanamayan riskler için özel fiyat belirleme bürosu (Triferingsbureau) ve Hollanda'da yine benzer bir büro (Rialto) kurulmuştur (www.iuscommune.eu).

- Malezya'da sigorta şirketleri tarafından sigortalanmayan riskler için 1992 yılında özel olarak havuz kurulmuş olup, başlangıçta iki sigorta şirketinin katılımıyla başlamış olan bu uygulamanın kapsamı, daha sonra başka şirketlerin de sisteme dâhil olmasıyla genişletilmiştir (Piam, 2019).

- Hindistan'da söz konusu risklerle ilgili olarak 2011 yılında zorunlu trafik sigortasında bir havuz kurulmakla birlikte, yıllar içinde havuz kapsamında yer alan sigortalıların sayısı azaldığından 2016 yılında bu havuz uygulamasına son verilmiştir ((International Actuarial of Association, 2017).

Görüleceği üzere, zorunlu trafik sigortasında prim artışlarının durdurulması ve aşırı riskli sigortalıların bir havuzda toplanarak prim ve hasarların sigorta şirketleri arasında paylaştırılmasına yönelik uygulamalar başka ülkelerde de bulunmaktadır. Ancak, yukarıda açıklanan azami prim tutarlarının belirlenmesi ve Riskli Sigortalılar Havuzunun oluşturulması şeklindeki uygulamalar kendine özgü çalışma prensipleri ile yalnızca ülkemiz sigortacılığında uygulanmakla, zorunlu trafik sigortalarına ilişkin dünya uygulamaları arasında yerini almıştır. Fakat belirtmek gerekir ki, yukarıda bahsedilen uygulamalar dünyada sayılı uygulamalardır. Zira zorunlu trafik sigortası için birçok Avrupa ülkesi dâhil dünya genelinde yaygın olan uygulama havuz veya benzeri uygulamalar olmayıp, fiyatların serbest piyasa ortamında oluşması şeklindedir.

\section{RİSKLİ SİGORTALILAR HAVUZ UYGULAMASINA İLISSKİN DEĞERLENDİRMELER}

Fiyatların tamamen serbestçe belirlendiği serbest piyasa uygulamasından farklı olan ve kamu otoritesi tarafından oluşturulan söz konusu havuz uygulamasının sigortacılık sektörüne bazı olumlu ve olumsuz etkilerinin olduğu veya olabileceği değerlendirilmektedir.

Olumlu etkileri:

Birincisi; tavan fiyat ve akabinde havuzun kurulmasıla birlikte trafik sigortasında teknik kâr/zarar oranında önemli ölçüde düşme yaşandığı veya bu branşta zararın azaltıldığg dolayısıyla sigortacılık sektörü için havuz uygulamasının olumlu olduğu görülmektedir.

İkincisi; havuz ile birlikte özellikle riskli gruplarda ortalama sigorta fiyatları önemli ölçüde düşmüş olup, hem sigorta yaygınlığının artırılması hem de sigortasızlığın azaltılması yönünde önemli bir adım atılmıştır.

Üçüncüsü; sigorta fiyatlarının yükselişinden dolayı oluşan kamuoyu tepkisi azalmıştır.

Olası olumsuz etkileri:

Birincisi; adil veya hakkaniyetli bir fiyatlamanın tam olarak yakalanamadığı düşünülmektedir. Zira havuz kapsamında fiyatlar kamu otoritesince, kişinin risk durumuna göre değil basamak bazında belirlenmektedir.

İkincisi; söz konusu havuz uygulamasının kötü sürücünün lehine, iyi sürücünün aleyhine bir durum oluşturduğu düşünülmektedir. Nitekim havuz kapsamında en riskli grupta yirmi adet kaza yapan ile üç adet kaza yapan için aynı azami prim tutarı söz konusudur. Benzer şekilde en risksiz grupta yirmi yıl kaza yapmayan ile üç yıl kaza yapmayan kişi için de aynı azami prim tutarı belirlenmiş durumdadır.

Üçüncüsü; havuzda tazminat veya hasar ödemeleri nispeten homojen bir şekilde dağıtılmaktadır. İlgili şirket havuzda oluşan tazminat ödemelerinden hasar payı oranında sorumlu olduğu için hasarın miktarı, şiddeti ve yönetilmesi konusunda ilave bir arzusu olmayacağından, tazminat ödemelerinin azaltılması hususunda yeterli motivasyonunun da bulunmayacağı düşünülmektedir.

Riskli sigortalılar havuzu uygulamasında kısa vadede sigorta fiyatları açısından arzulanan hedefe varılmış, sigorta fiyatlarının düşmesiyle sigortalılara ve zararın azalmasıyla sigortacılık sektörüne bir fayda getirmiştir. Kamu otoritesi açısından kısa vadede en doğru çözümün bu olduğu kabul edilebilir. Ancak, yukarıda yer alan olumsuz etkiler de dikkate alınarak sigorta tekniği açısından orta ve uzun vadede havuz uygulamasının tekrar gözden geçirilmesi önemlidir. Zira sigorta şirketleri havuz uygulamasında sadece bir aracı olarak çalışmakta ve zorunlu trafik sigortası branşında başta hasarın azaltılması olmak üzere uzmanlaşma ve iyileştirme yönünde bir motivasyonunun bulunmadığı düşünülmektedir.

Ayrıca, ülkemizde yer alan havuz uygulamasına benzer örnekler diğer ülkelerde de yer almaktadır. Ancak yukarıda bahsedilen uygulamalar dünyada sayılı örneklerdir. Dolayısıyla dünyada yaygın uygulama fiyatların, sigortalılarla sigorta şirketlerinin karşılıklı bir araya geldiği serbest piyasa ortamında belirlenmesidir.

Sonuç olarak, sigorta fiyatlarının makul seviyeye ulaşmasını ve iyi-kötü sürücü ayrımı yapılabilmesini teminen ayrıca serbest piyasa ortamının sağlanması veya kişiyi risk temelinde fiyatlayan bir modelin 
oluşturulması seçeneklerinin de orta ve uzun vadede yeniden değerlendirilmesinin uygun olacağı değerlendirilmektedir.

\section{SONUÇ}

Zorunlu trafik sigortası fiyatlarının belirlenmesi hususunda Türk sigortacılık sektöründe farklı uygulamalar oluşmuştur. Söz konusu sigortada ülkemizde yaşanan fiyat hassasiyetinden dolayı kamu otoritesi tarafindan müdahaleler yapılmıştır. Bu müdahalelerin amacı; fiyatların ne sigortalılar için yüksek ne de sigorta şirketleri için düşük olacak şekilde makul düzeye getirilmesidir. Çünkü birinci durum sigortasızlığa ikinci durum ise sigortacılık şirketlerinin zarar etmesine neden olacak, böylece sektörde bir denge oluşmayacaktır. Genel olarak kamu otoritesi tarafindan yapılan müdahaleler ve düzenlemeler; fiyatların aşırı yükselmesine karşı yapılmış olup, alınan önlemler arasında, teminat içeriğinin ilgili Kanun ile somut hale getirilmesi, sigortasızlığa sebebiyet vermeyecek makul bir fiyat seviyesinin oluşturulmasına yönelik tarifenin, diğer bir deyişle fiyatların doğrudan kamu otoritesi tarafından belirlenmesi şeklinde olmuştur.

Nitekim fiyatların makul seviyeye getirilmesini teminen kamu otoritesi tarafindan öncelikle tavan fiyat uygulaması getirilmiş, akabinde ise sigorta şirketlerinin hasar frekansı yüksek araç gruplarını sigortalamaktan imtina ettikleri gözlemlenerek bu sorunun çözümü amacıyla Riskli Sigortalılar Havuzu kurulmuştur.

İlerleyen yıllarda Riskli Sigortalılar Havuzunun sigortac1lık sektörüne olan etkilerinin daha net görülebileceği kabul edilerek, özellikle havuz kapsamında tutulan ve istatistiki çalışmaya imkân veren verilerin toplanmasıyla bu yöndeki çalışmaların analiz edilmesinde fayda görülmektedir. Sonuç olarak ileride oluşacak etki ve yapılacak analizler ve diğer ülke örneklerinin de yakından takip edilmesi sonucunda, tekrar serbest tarife veya kişi temelli poliçe seçeneklerini de dikkate alarak havuz uygulamasının yeniden gözden geçirilmesinin uygun olacağı değerlendirilmektedir. 


\section{KAYNAKÇA}

Bağriaçık, Safiye Nur, (2016), Karayolları Zorunlu Mali Sorumluluk Sigortasında Sigortacının Sorumluluğu.

Baykal, Kemal Burak ve Bülbül, Serpil Ergün, (2016), "Türkiye'de Trafik Sigortalarında Optimal Ödül-Ceza Sistemi Tasarımı: İyi Risk/Kötü Risk Modeli”, Finansal Araştırmalar ve Çalışmalar Dergisi, 8 (14), s. 17-31.

Karasu, Rauf, (2016), Karayolları Zorunlu Mali Sorumluluk Sigortası (Trafik Sigortası), Yetkin:Ankara

Kayıhan, Şaban, (2016), "Zorunlu mali mesuliyet sigortasında (ZMMS= Trafik sigortası) sigorta ettirenin kendi tam kusuru ile vefatı halinde mirasçıların üçüncü kişi sıfatıyla müteveffanın sigortacısına başvurmaları durumuna ilişkin hukuki düşünceler.”, Marmara Üniversitesi Hukuk Fakültesi Hukuk Araştırmaları Dergisi, 22(1) s. 251263.

Milli Reasürans T.A.Ş., (2004), Açıklamalı Sigorta ve Reasürans Terimleri Sözlüğü, (1. Baskı), Ceyma:İstanbul.

Sarı, Özlem Güldoğan, (2010), "Karayolları Motorlu Araçlar Zorunlu Mali Sorumluluk Sigortası Uygulamaları Işığında Hasar Analizi”, Yayınlanmamış Yüksek Lisans Tezi, YÖK Ulusal Tez Merkezi veri tabanından elde edilmiştir. (Tez no: 274551).

Temur, Abdülnaim, (2018), “Türkiye'de Trafik Sigortalarının Branş Karlılığını Etkileyen Faktörler ve Bu Faktörlerin Sigorta Sektörü Karlılı̆̆ına Etkisi”, Akademik Hassasiyetleri, 5(10), s. 305-330.

Tunç, Cüneyt ve Akpınar, Özgür, (2018), "Zorunlu Trafik Sigortasındaki Mevzuat Kaynaklı Değişikliklerin Prim Üretimine Etkisinin Analizi”, Uşak Üniversitesi Sosyal Bilimler Dergisi, 11(3), s. 221-236.

Ulaş, Işı1, (1992), Uygulamalı Sigorta Hukuku Mal ve Sorumluluk Sigortaları, Turhan:Ankara.

Ünan, Samim ve Baysal, Başak, (2012), "Trafik Kazası Sebebiyle Destekten Yoksun Kalanların Araç İşletenin Sorumluluk Sigortacısına Yönelttiği İstemlerle İlgili Yargıtay Kararlarının Değerlendirilmesi”, Ticaret Hukuku ve Yargıtay Kararları Sempozyumu XXVI, Bildiriler - Tartı̧̧alar. Bankacılık ve Ticaret H. Araş, E, s.99-124.

Yalçınkaya, Aslıhan, (2019), "Genel Hatları İle Karayolları Zorunlu Mali Sorumluluk Sigortası", Ankara Barosu Dergisi,1.

Çelik, Ahmet, (2019), "Zorunlu Mali Sorumluluk Sigortası (Trafik Sigortası”, Erişim Tarihi: 27.02.2019 http://www.tazminathukuku.com/arastirma-yazilari/zorunlu-mali-sorumluluk-sigortasi-trafik-sigortasi.htm

Doğan, Noyan, (2017), "Trafik Sigortasına Tavan Fiyat", Erişim Tarihi 17.02.2019. http://www.hurriyet.com.tr/yazarlar/noyan-dogan/trafik-sigortasina-tavan-fiyat-40400469

Editör, (2015), "Zorunlu Trafik Sigorta Ücretleri Aşırı Yükseldi, Erişim Tarihi: 27.02.2019. http://yenierdekgazetesi.com/haber/zorunlu-trafik-sigorta-ucretleri-asiri-yukseldi-17328.html

Editör, (2016), "Bir yılda trafik sigortasına yüzde 129 zam olur mu?" Erişim Tarihi: 27.02.2019. https://www.memurlar.net/haber/566126/bir-yilda-trafik-sigortasina-yuzde-129-zam-olur-mu.html

Editör, (2017), "Trafik Sigortasında Tavan Fiyat Uygulaması", Erişim Tarihi: 17.02.2019. https://www.ensonhaber.com/trafik-sigortasinda-tavan-fiyat-uygulamasi-2017-03-20.html

Güvence Hesab1, https://www.guvencehesabi.org.tr/

Hazine ve Maliye Bakanlığı, (2019), Erişim Tarihi 20.02.2019. https://www.hmb.gov.tr/sigortacilik-ve-ozel-emeklilikmevzuat

Hazine ve Maliye Bakanlı̆̆ının 2015/55 sayılı Genelgesi, Erişim Tarihi: 17.02.2019. https://www.tsb.org.tr/images/Documents/2015-55\%20Say\%C4\%B11\%C4\%B1\%20Genelge.pdf

Hazine ve Maliye Bakanlığını 2017/1 sayılı Genelgesi, Erişim Tarihi 17.02.2019. https://www.tsb.org.tr/images/Documents/2017-1\%20Genrlgr.pdf

Insurance Information Institute, Erişim Tarihi: 24.03.2019. https://www.iii.org/publications/a-firm-foundation-howinsurance-supports-the-economy/a-50-state-commitment/residual-markets

$\begin{array}{lllll}\text { International Actuarial of } & \text { Association, } & \text { Erişim } & \text { Tarihi: } & \text { 24.019.20 }\end{array}$ http://www.actuaries.org/FUND/Turkey_2017/Presentations/FBois_MotorInsurancePools.pdf

Kantar, C. (2013), "Sigorta Şirketlerinin Bedeni Hasar Çıkmazı”, Erişim Tarihi: 15.02.2019. https://www.dunya.com/kose-yazisi/sigorta-sirketlerinin-quotbedeni-hasarquot-cikmazi/17517

Karayolları Motorlu Araçlar Zorunlu Mali Sorumluluk Sigortası Genel Şartları İlgili Genel Şartları https://www.tsb.org.tr/EditHtmlModule.aspx?pageID=1080\&mid=3084

Karayolları Motorlu Araçlar Zorunlu Mali Sorumluluk Sigortasında Tarife Uygulama Esasları Hakkında Yönetmelik: https://www.tsb.org.tr/default.aspx?pageID=654\&yid=6

PIAM, Erişim Tarihi: 25.03.2019, http://www.piam.org.my/media/annual-reports/annual-report-2010/malaysian-motorinsurance-pool-mmip/

Price Waterhouse Coopers, PWC, "The Italian Insurance Market", Erişim Tarihi: 24.03.2019. http://www.icetokyo.or.jp/wp-content/uploads/2017/05/201609insurancePWC.pdf

Rekabet Kurumu, Erişim Tarihi: 17.02.2019, https://www.rekabet.gov.tr/tr/Guncel/trafik-sigortasi-pazarinda-faaliyetgost-e99dc8134905416eb2a3365f6e4ff423?AspxAutoDetectCookieSupport=1

Resmi Gazete, "Karayolları Motorlu Araçlar Zorunlu Mali Sorumluluk Sigortası Primlerine İlişkin Genelge": https://www.tsb.org.tr/images/Documents/2017-1\%20Genrlgr.pdf

Resmi Gazete "Sigorta ve Reasürans ile Emeklilik Şirketlerinin Sermaye Yeterliliklerinin Ölçülmesine ve Değerlendirilmesine İlişkin Yönetmelikte Değişiklik Yapılmasına Dair Yönetmelik”: http://www.resmigazete.gov.tr/main.aspx?home= 
Resmi Gazete, Karayolları Motorlu Araçlar Zorunlu Mali Sorumluluk Sigortasında Tarife Uygulama Esasları Hakkında Yönetmelikle Değişiklik Yapılmasına Dair Yönetmelik: http://www.resmigazete.gov.tr/main.aspx?home=

Sigorta Bilgi ve Gözetim Merkezi: www.sbm.org.tr

Sigortam.net, (2016), “Trafik Sigortası Fiyatları Neden Artıyor?”, Erişim Tarihi: 18.03.2019. https://www.sigortam.net/trafik-sigortasi/trafik-sigortasi-fiyatlari-neden-artiyor

Sisk, A. (2018), “What Is Risk Pooling in Insurance?”, Erişim Tarihi: 12.03.2019. https://bizfluent.com/about-6521384risk-pooling-insurance-.html

Special Insurance Systems For Motor Vehicle Liability In Belgium And The Netherlands, Erişim Tarihi: 25.03.2019,http://www.iuscommune.eu/html/activities/2013/2013-11-28/workshop9a_De_Mot_and_Faure.pdf

Özkap, Seval, (2016), "Poliçeler Artık Ehliyete Özel Olacak”, Erişim Tarihi: 20.02.2019. https://www.sigortamedya.com.tr/policeler-artik-ehliyete-ozel-olacak/

Türkiye İstatistik Kurumu, Erişim Tarihi: 20.02.2019. http://tuik.gov.tr/UstMenu.do?metod=temelist

Türkiye Sigorta Birliği, Erişim Tarihi: 17.02.2019., https://www.tsb.org.tr/images/Documents/Azami\%20Prim2.pdf

Türkiye Sigorta Birliği, Erişim Tarihi: 24.02.2019, https://www.tsb.org.tr/EditHtmlModule.aspx?pageID=1080\&mid=3084

Türkiye Sigorta Birliği, Erişim Tarihi: 25.02.2019, https://www.tsb.org.tr/default.aspx?pageID=654\&yid=6

Türkiye Sigorta Birliği, Erişim Tarihi: 27.02.2019, https://www.tsb.org.tr/images/Documents/2017-1\%20Genrlgr.pdf

Türkiye Sigorta Birliği, Erişim Tarihi: 01.03.2019, https://www.tsb.org.tr/resmi-istatistikler.aspx?pageID=909

Türkiye Sigorta Birliği, Erişim Tarihi: 03.03.2019, https://www.tsb.org.tr/mulga-kanun-genelge-teblig-ve-sektorduyurulari.aspx?pageID=1128\#1443

Türkiye Sigorta Birliği, Erişim Tarihi: 05.03.2019, https://www.tsb.org.tr/images/Documents/2015$55 \% 20$ Say\%C4\%B11\%C4\%B1\%20Genelge.pdf

2918 Sayılı Karayolları Trafik Kanunu:

https://www.tsb.org.tr/Document/Yonetmelikler/Trafik\%20Kanunu_18072018.pdf

5684 Sayılı Sigortac1lik Kanunu: https://www.tsb.org.tr/Document/Yonetmelikler/1.5.5684.pdf

https://www.memurlar.net/haber/566126/bir-yilda-trafik-sigortasina-yuzde-129-zam-olur-mu.html 